\title{
Analisis Potensi Likuifaksi Menggunakan Metode Castro (1975) Pada Lapisan Keras Tanah Pasir di Bawah Gedung Islamic Center At-Taqarrub Trienggadeng Pidie Jaya
}

\author{
Syifa Nabila ${ }^{1, *}$ Munirwansyah $^{2}$ Munira Sungkar $^{3}$ \\ ${ }^{1}$ Mahasiswa, Jurusan Teknik Sipil, Universitas Syiah Kuala, Banda Aceh 23111, Indonesia \\ 2,3 Jurusan Teknik Sipil, Universitas Syiah Kuala, Banda Aceh 23111, Indonesia. \\ email: syifanblaa@gmail.com
}

\begin{abstract}
The earthquake that occurred in Pidie Jaya was a tectonic earthquake originating from the Pidie fault with a magnitude of 6.5 SR. The earthquake caused a variety of damage to the region, one of which is liquefaction. Liquefaction is a phenomenon of loss of ground forces due to vibration. This phenomenon occurs in sandy soils in saturated and loose conditions. This research was conducted on a layer of sand under the At-Taqarrub Islamic Center building TrienggadengPidie Jaya. To analyze the potential of this liquefaction is done at 2 drill points using the methods Castro (1975 while the average earthquake acceleration data at ground level was analyzed using Kawashumi method. The planned earthquake magnitude are 5.0, 6.0, 6.5, 7.5 and 9.0 SR. The results of this study that at drill log 1 and drill $\log 2$ are liquefaction did not occur in every layer and every planned earthquake magnitude.
\end{abstract}

Keywords: earthquake, liquefaction potential, sand layer, magnitude

\begin{abstract}
Abstrak
Gempa yang terjadi yaitu gempa yang terjadi di Kabupaten Pidie Jaya merupakan gempa tektonik yang bersumber gempa dari sesar Pidie dengan kekuatan 6,5 SR. Gempa tersebut menyebabkan berbagai kerusakan pada wilayah tersebut salah satunya yaitu likuifaksi. Likuifaksi merupakan fenomena hilangnya kekuatan lapisan tanah akibat getaran. Fenomena tersebut terjadi pada tanah pasir dalam kondisi jenuh dan lepas. Penelitian ini dilakukan pada lapisan pasir di bawah gedung Islamic Center At-Taqarrub Trienggadeng, Pidie Jaya. Untuk menganalisis potensi likuifaksi ini dilakukan pada 2 titik bor dengan menggunakan metode Castro (1975) sedangkan data percepatan gempa rata-rata dipermukaan tanah dianalisis menggunakan metode Kawashumi. Magnitude gempa yang direncanakan yaitu sebesar 5.0, 6.0, 6.5, 7.5, dan 9.0 SR. Hasil dari penelitian ini yaitu pada titik bor log 1 dan titik bor log 2 tidak mengalami likuifaksi disetiap kedalaman dan setiap magnitude gempa yang direncanakan.
\end{abstract}

Kata Kunci : gempa bumi, potensi likuifaksi, lapisan pasir, magnitude gempa

\section{Pendahuluan}

Indonesia merupakan negara yang berada di jalur gempa teraktif di dunia karena dikelilingi oleh cincin api pasifik dan berada di atas tiga tumbukan lempeng benua. Oleh karena itu Aceh yang terletak di ujung Pulau Sumatera dan terletak di sekitar Pantai Barat Sumatera yang merupakan daerah pertemuan dari plat tektonik, patahan Sumatera, patahan-patahan lokal, dan gunung api Seulawah mengakibatkan Aceh menjadi daerah aktif gempa. Menurut PUSGEN [1], aktivitas gempa di wilayah Sumatera naik dengan drastis setelah terjadinya gempa-tsunami Aceh tahun 2004 yang mengakibatkan sebanyak 173.741 jiwa meninggal, 116.368 orang dinyatakan hilang, serta mengakibatkan ribuan rumah dan bangunan rusak.

Badan Meteorologi, Klimatologi, dan Geofisika (BMKG) mengumumkan bahwa pada tanggal 07 Desember 2016 tepatnya pukul 05.03.36 WIB terjadi gempa bumi di Kabupaten Pidie Jaya yang merupakan gempa tektonik dengan kekuatan 6,5 SR pada kedalaman $15 \mathrm{~km}$ dan pusat gempa berada di koordinat 5,25 LU dan 96,24 BT, tepatnya di darat pada jarak $106 \mathrm{~km}$ arah tenggara Kota Banda Aceh. Gempa Pidie Jaya tersebut mengakibatkan banyak kerusakan infrastruktur pada daerah tersebut dan juga adanya potensi likuifaksi dibeberapa wilayah. Akibat banyaknya kerusakan yang terjadi pasca bencana gempa bumi tersebut maka dilakukan pembenahan dengan pembangunan kembali fasilitas-fasilitas dan infrastruktur-infrastruktur yang rusak. Salah satunya yaitu pembangunan kembali Islamic Center At-Taqarrub, Trienggadeng yang terletak pada 5,26 LU dan 96,18 BT. Masjid tersebut merupakan salah satu tempat ibadah umat islam yang rusak akibat gempa bumi dan menjadi objek penelitian ini. Dapat dilihat dalam Gambar 1 berikut ini.

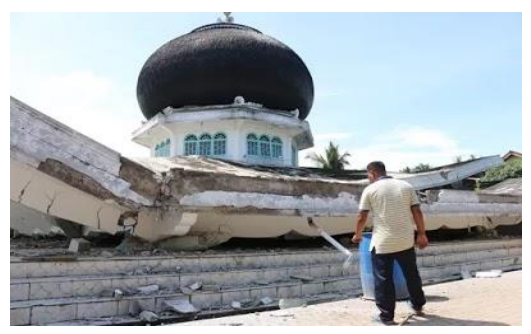

Gambar 1 Masjid setelah mengalami keruntuhan akibat gempa 2016 yang berkekuatan 6,5 SR. 
Likuifaksi merupakan sebuah kerusakan yang harus diperhatian untuk suatu struktur yang dibangun di atas tanah berpasir jenuh. Likuifaksi adalah suatu fenomena perubahan kondisi tanah dari keadaan padat menjadi cair yang umumnya terjadi pada tanah pasiran dalam kondisi jenuh dan lepas. Likuifaksi menyebabkan tanah tidak dapat menahan beban yang berada diatasnya (upper structure) dan akan terjadi kerusakan-kerusakan pada struktur yang berada diatasnya, bahkan bagian struktur atas (upper structure) tersebut dapat mengalami kerusakan ringan, kerusakan berat atau keruntuhan serta miring ke arah tertentu (failure).

Tujuan dari penelitian ini adalah menganalisis kemungkinan terjadinya keruntuhan struktur pasir (potensi likuifaksi) pada saat terjadinya gempa bumi dengan menggunakan metode Castro (1975) dengan sumber gempa yaitu sesar Pidie dengan magnitude gempa 6,5 SR.

\section{Tinjauan Kepustakaan}

\subsection{Mekanisme Terjadinya Likuifaksi}

Menurut Seed et al., (1975) yang dikutip dari Marwan et al. [2] menyebutkan bahwa untuk menganalisis kemungkinan terjadi likuifaksi diasumsikan bahwa selama berlangsungnya getaran gempa belum terjadi dissipasi yang berarti dengan perkataan lain belum terjadi redistribusi tekanan air pori pada masa tanah. Akibat beban cyclic, tanah mengalami tekanan sebelum air sempat keluar dari pori-pori tanah. Hal ini menyebabkan tekanan air pori meningkat, sebaliknya tegangan efektif berkurang dan dengan demikian kekuatan geser menjadi berkurang.

Perubahan sifat solid ke sifat liquid yang terjadi pada pasir jenuh air ini diakibatkan oleh peningkatan tekanan air pori dan pengurangan tegangan efektif. Hal ini dapat dijelaskan dengan menggunakan rumus tegangan efektif dan rumus kekuatan geser tanah dari Terzaghi, Persamaan tegangan efektif menurut Bowles [3] dapat dilihat pada persamaan 1 sebagai berikut:

$\sigma_{\text {eff }}=\sigma_{\text {tot }}-\mathrm{u}$

di mana:

$\sigma_{\text {eff }} \quad=$ tegangan yang sebenarnya bekerja pada butir tanah $\left(\mathrm{kg} / \mathrm{cm}^{2}\right)$;

$\sigma_{\text {tot }} \quad=$ tegangan akibat beban-beban yang bekerja $\left(\mathrm{kg} / \mathrm{cm}^{2}\right)$; dan

$\mathrm{u} \quad=$ tekanan air pori $\left(\mathrm{kg} / \mathrm{cm}^{2}\right)$.

Rumus kekuatan geser menurut Bowles [3] dapat dilihat pada persamaan 2 sebagai berikut:

$\mathrm{S}=\mathrm{c}+\sigma_{\text {eff }} \cdot \tan \varphi$

di mana:

$\mathrm{S} \quad=$ kekuatan geser tanah $\left(\mathrm{kg} / \mathrm{cm}^{2}\right)$;

c $\quad=\operatorname{kohesi}\left(\mathrm{kg} / \mathrm{cm}^{2}\right) ;$ dan

$\varphi \quad=$ sudut geser $\left({ }^{\circ}\right)$.
Terlihat dari kedua rumus di atas bahwa peningkatan tekanan air pori akan berarti mengurangi tegangan efektif dan sekaligus mengurangi kekuatan geser dari tanah yang bersangkutan.

\subsection{Evaluasi Potensial Likuifaksi menggunakan Metode Castro}

Menurut Castro (1975) yang dikutip dari Marwan et al. [2] suatu grafik yang menyatakan hubungan antara nilai tahanan penetrasi standar yang telah dikoreksi (N') pada kedalaman tanah yang ditinjau dengan nilai rasio tegangan gempa rata-rata $\left(\tau_{\mathrm{av}} / \sigma^{\prime}{ }_{\mathrm{vo}}\right)$, dimana $\tau_{\mathrm{av}}$ adalah tegangan geser gempa rata-rata dan $\sigma_{\text {vo }}$ adalah tegangan vertikal efektif, seperti yang diperlihatkan pada Gambar 2.

Pada gambar 2, terdapat dua garis lengkung yang merupakan garis batas, dimana sebelah kanan garis menunjukkan tidak terjadi likuifaksi sedangkan sebelah kiri garis menunjukkan terjadinya likuifaksi. Dari gambar juga dapat diketahui bahwa untuk nilai N' yang melebihi 50, tidak terjadi likuifaksi disebabkan garis likuifaksi hanya terbatas pada nilai N' sampai 50 .

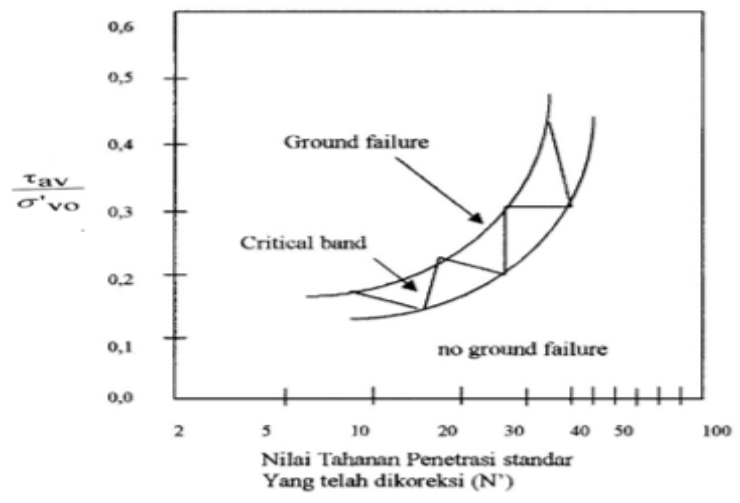

Gambar 2. Cyclic Stress Ratio vs Nilai SPT yang Terkoreksi

Sumber : Castro,1975 (dikutip dari Marwan et al.[2])

Nilai tahanan standar penetrasi yang dikoreksi, dapat didapatkan dengan persamaan yang diberikan oleh Teng, 1962 sebagaimana dikutip oleh Susantri [4] dapat dilihat pada persamaan 3 sebagai berikut:

$\mathrm{N}^{\prime}=\frac{50 . \mathrm{N}}{\sigma_{v o}^{\prime}+10}$

di mana:

$\mathrm{N}^{\prime} \quad$ = nilai SPT yang dikoreksi (blow/ft);

$\mathrm{N} \quad=$ nilai SPT yang sebenarnya $($ blow/ft); dan

$\sigma^{\prime}{ }_{\text {vo }} \quad=$ tegangan vertikal efektif yang nilainya $<280$ $\mathrm{kN} / \mathrm{m}^{2}$.

Nilai tegangan geser gempa rata-rata yang terjadi pada bidang horizontal, oleh Castro dinyatakan pada persamaan 4 sebagai berikut:

$\tau_{\mathrm{av}}=0,7 \cdot \frac{\sigma_{v o}}{\mathrm{~g}} \cdot \mathrm{a} \max \mathrm{rd}$ 
di mana:

$\tau_{\mathrm{av}} \quad=$ nilai tegangan geser gempa rata-rata $\left(\mathrm{kg} / \mathrm{cm}^{2}\right) ;$

$\sigma_{\text {vo }} \quad=$ tegangan total $\left(\mathrm{kg} / \mathrm{cm}^{2}\right)$;

$\mathrm{g} \quad=$ percepatan gravitasi bumi $\left(\mathrm{cm} / \mathrm{det}^{2}\right)$;

$\mathrm{a}_{\max } \quad=$ percepatan gempa makismum di permukaan tanah (gal); dan

rd = faktor reduksi sebagai tegangan fungsi dari kedalaman yang dapat dilihat dalam Gambar 4 di bawah.

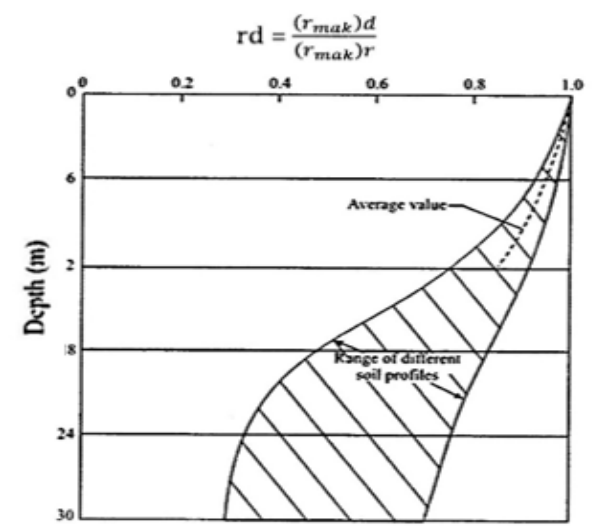

Gambar 3. Nilai rata-rata rd

Sumber : Mase, 2014 (dikutip dari Marwan et al.[2])

Apabila data tanah yang diperlukan tidak cukup tersedia, jika nilai $\mathrm{N}$ tidak didapat dari pekerjaan boring di lapangan dan nilai-nilai berat volume tanah tidak tersedia dari hasil tes laboratorium maka kedua data tersebut dapat ditentukan berdasarkan Tabel 1 di bawah ini.

Tabel 1. Korelasi Uji Penetrasi Standar

\begin{tabular}{|c|c|c|c|}
\hline Keadaan & $\begin{array}{c}\text { Jumlah } \\
\text { Tumbukan, } \\
\mathrm{N} \\
\text { (Blow/Feet) }\end{array}$ & $\begin{array}{c}\text { Berat Isi, } \\
\gamma \\
\left(\mathrm{kN} / \mathrm{m}^{3}\right)\end{array}$ & $\begin{array}{c}\text { Sudut } \\
\text { Gesek, } \\
\phi \\
\left(^{\circ}\right)\end{array}$ \\
\hline Lepas & $0-10$ & $12-16$ & $25-32$ \\
\hline Sedang & $11-30$ & $14-18$ & $28-36$ \\
\hline Padat & $31-50$ & $16-20$ & $30-40$ \\
\hline Sangat padat & $>50$ & $18-23$ & $>35$ \\
\hline
\end{tabular}

Sumber : Bowles [3]

\subsection{Hubungan Empiris Parameter Gempa}

Durasi getaran gempa dipengaruhi oleh besarnya magnitude gempa karena getaran tersebut akan berlangsung minimal selama tidak terjadinya geseran pada patahan. Percepatan gempa dan magnitude gempa mempunyai hubungan empiris sebagai berikut :

Menurut persamaan Kawashumi hubungan tersebut adalah :

$\log \mathrm{a}=\mathrm{M}-5,45-0,00084(\mathrm{~d}-100)+\log (100 / \mathrm{d}) *(1 / 0,43429) \ldots(5)$

di mana:

$\mathrm{M} \quad=$ magnitude gempa (Skala Richter);

a $\quad=$ percepatan gempa di permukaan tanah (gal);

$\mathrm{d}=$ jarak hiposentrum dari sumber gempa $(\mathrm{km})$.

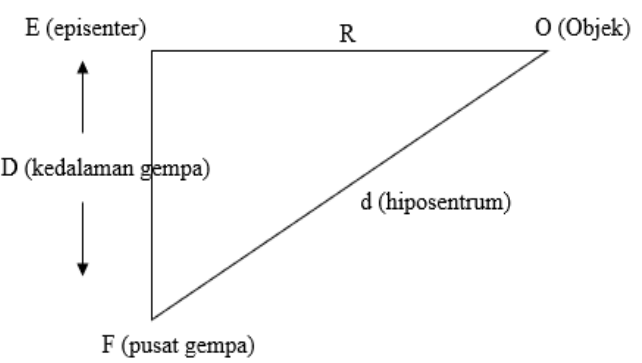

Gambar 4. Ilustrasi Jarak Horizontal dari Pusat Gempa Bumi

Sumber : Bradja, 1983 (dikutip dari Susantri [4])

Pada Gambar 4, dihasilkan jarak hiposentrum (d) dari pusat gempa yang diperoleh menggunakan rumus phitagoras dengan memasukkan jarak kedalaman gempa (D) dan jarak horizontal (R) dari pusat gempa. Sedangkan untuk mendapatkan jarak horizontal $(\mathrm{R})$ yaitu dengan memasukkan koordinat episenter dan koordinat $\mathrm{O}$ (objek) sebagai berikut:

$\operatorname{Cos} \mathrm{ER}(\mathrm{R})=\sin \phi \mathrm{E} \cdot \sin \phi \mathrm{O}+\cos \phi \mathrm{E} \cdot \cos \phi \mathrm{O} \cdot \cos (\mathrm{LE}-\mathrm{LO})$

di mana,

$\phi \mathrm{E} \quad=$ koordinat bujur episenter $\left({ }^{\circ}\right)$;

$\phi \mathrm{O}=$ koordinat bujur objek $\left({ }^{\circ}\right)$;

$\mathrm{LE}=$ koordinat lintang episenter $\left({ }^{\circ}\right)$; dan

LO $=$ koordinat lintang objek $\left(^{\circ}\right)$.

\section{Metode Penelitian}

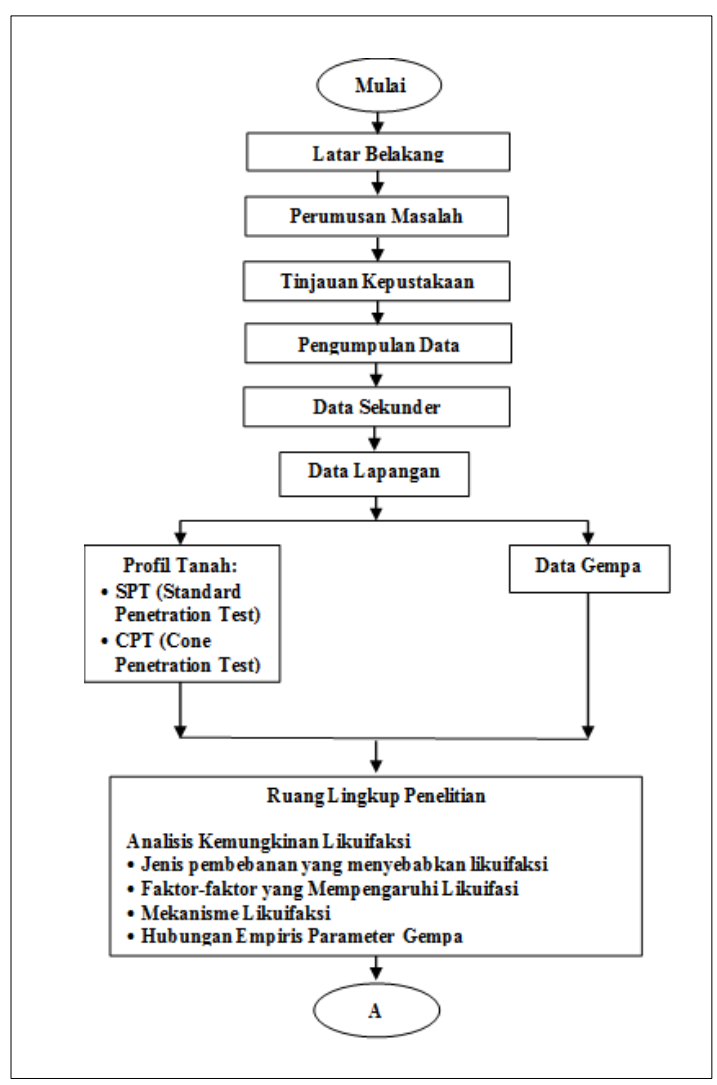

Gambar 5. Bagan Alir Penelitian 


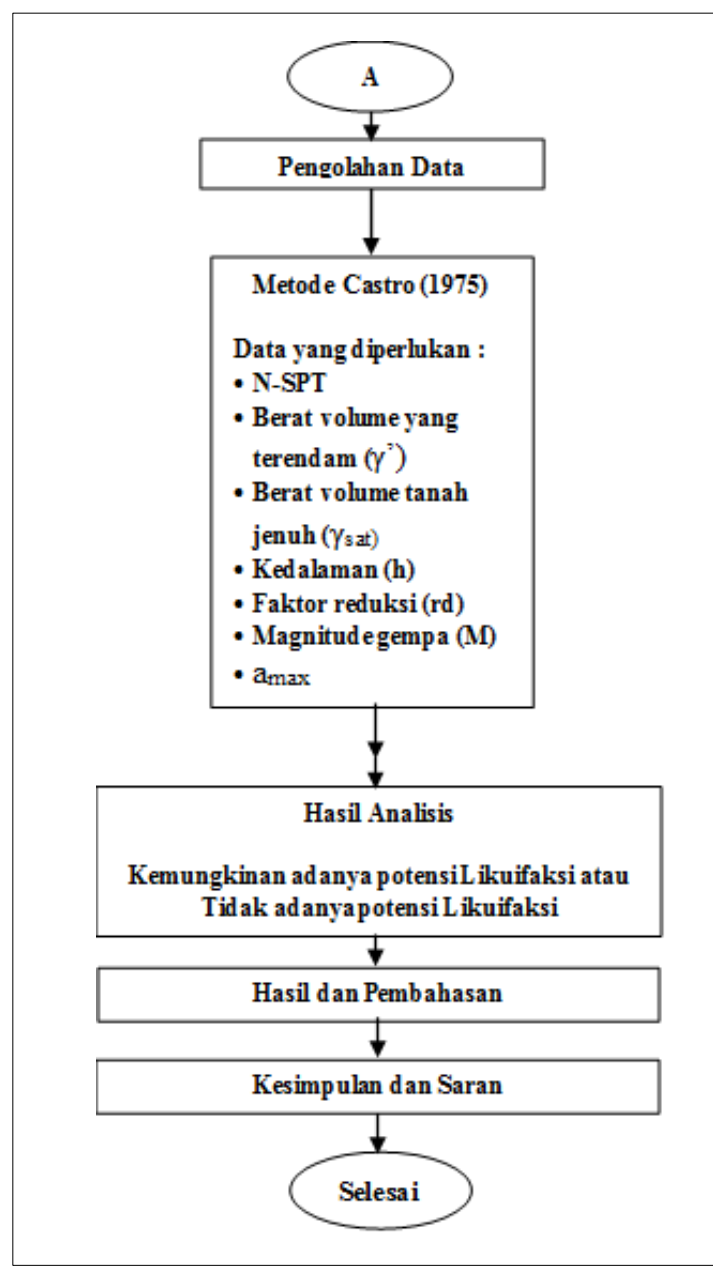

Gambar 6. Bagan Alir Penelitian

Pada penulisan ini yang ditinjau hanya masalah likuifaksi akibat beban siklis (cyclic) yang pada sebutan berikutnya hanya disebut dengan likuifaksi saja. Potensi likuifaksi ini dianalisis menggunakan metode perhitungan Castro (1975). Jenis dan sumber data yang digunakan dalam penelitian ini adalah data yang berasal dari data lapangan (sekunder). Tiap lapisan tanah yang ditinjau pada penelitian ini terbatas pada titik-titik yang berada pada lokasi gedung Islamic Center At-Taqarrub Trienggadeng, Pidie Jaya. Adapun data lapangan ini meliputi profil tanah. Data profil tanah ini didapat dari laporan hasil penyelidikan yang dilakukan oleh $\mathrm{CV}$. Rekayasa Andalan [5]. Data profil tanah ini digunakan untuk mengetahui lapisan-lapisan tanah pasir yang terdapat pada objek penelitian ini. Data profil tanah yang digunakan berupa susunan jenis lapisan tanah (bor log).

Data magnitude gempa yang dipakai yaitu radius gempa maksimum $500 \mathrm{~km}$ dari lokasi yang ditinjau dikumpulkan dari Badan Meteorologi dan Geofisika (BMKG) Mata Ie, Banda Aceh [6]. Data yang ada merupakan data gempa dari tahun 1999 sampai dengan Juli 2019. Radius sejarak ini dipertimbangkan untuk mendapatkan data gempa yang lebih memadai.

Untuk tiap kejadian gempa, data tersebut merupakan nilai besaran (magnitude) gempa, dan letak sumber gempa (koordinat lintang dan bujur pada bola bumi, kedalaman, tanggal dan tahun kejadiannya). Penentuan magnitude gempa untuk analisis potensi likuifaksi adalah besaran yang terbesar dari data pencatatan magnitude gempa yang pernah terjadi dan diperhitungkan sebagai magnitude gempa desain.

\section{Hasil dan Pembahasan}

\subsection{Hasil}

Hasil penelitian dan pengolahan data yang disajikan dalam bab ini meliputi perhitungan parameter likuifaksi, yaitu magnitude gempa, percepatan gempa maksimum $\left(\mathrm{a}_{\max }\right)$ pada permukaan tanah, tegangan efektif, tegangan total lalu dilanjutkan dengan analisis potensi likuifaksi menggunakan metode Castro (1975).

\subsubsection{Magnitude Gempa (M)}

Data gempa yang diperoleh Badan Meteorologi Klimatologi dan Geofisika (BMKG), Stasiun Geofisika Mata Ie Banda Aceh (2019). Data tersebut merupakan catatan gempa yang pernah terjadi di daerah Aceh dan sekitarnya dari kurun waktu Januari 1999 sampai dengan Juli 2019 dengan magnitude gempa $\mathrm{M} \geq 5$ 5,0 Skala Richter. Berdasarkan data magnitude gempa tersebut, maka magnitude gempa desain untuk penelitian ini diambil dari urutan 5, 6, 6.5, 7, dan 9 Skala Richter karena gempa dengan magnitude gempa $\mathrm{M} \geq 5,0$ Skala Richter bersifat merusak pada suatu konstruksi bangunan.

\subsubsection{Percepatan Gempa pada Permukaan Tanah (a)}

Nilai percepatan gempa di permukaan tanah diperoleh dari pengolahan data magnitude gempa dengan menggunakan teori-teori yang terdapat di Bab 2. Nilai percepatan gempa di permukaan tanah yang digunakan pada desain adalah nilai percepatan gempa maksimum di permukaan tanah. Berikut ini adalah perhitungan percepatan gempa yang dipilih. Nilai-nilai tersebut dihitung berdasarkan persamaan Kawashumi seperti pada tabel 2 dan menghasilkan gambar 7 seperti dibawah ini.

Tabel 2. Data Perhitungan Percepatan Gempa

\begin{tabular}{cccccc}
\hline No Kedalaman & Magnitude & $\begin{array}{c}\mathrm{R} \\
(\mathrm{Km})\end{array}$ & $\begin{array}{c}\mathrm{d} \\
(\mathrm{Km})\end{array}$ & $\mathrm{a} \max (\mathrm{g})$ \\
\cline { 5 - 6 } & $(\mathrm{km})$ & & & & Kawashumi \\
\hline 1 & 15 & 5,0 & 6,736 & 16,443 & 0,00003 \\
\hline 6 & 15 & 5,5 & 6,736 & 16,443 & 0,00009 \\
\hline 11 & 15 & 6,0 & 6,736 & 16,443 & 0,00027 \\
\hline 15 & 15 & 6,5 & 6,736 & 16,443 & 0,00086 \\
\hline 16 & 15 & 6,6 & 6,736 & 16,443 & 0,00108 \\
\hline 17 & 15 & 6,8 & 6,736 & 16,443 & 0,00171 \\
\hline 18 & 15 & 7,0 & 6,736 & 16,443 & 0,00272 \\
\hline 19 & 15 & 7,2 & 6,736 & 16,443 & 0,00430 \\
\hline 20 & 15 & 7,3 & 6,736 & 16,443 & 0,00542 \\
\hline 21 & 15 & 7,5 & 6,736 & 16,443 & 0,00859 \\
\hline 22 & 15 & 7,8 & 6,736 & 16,443 & 0,01713 \\
\hline 23 & 15 & 8,6 & 6,736 & 16,443 & 0,10809 \\
\hline 24 & 15 & 9,0 & 6,736 & 16,443 & 0,27152 \\
\hline
\end{tabular}




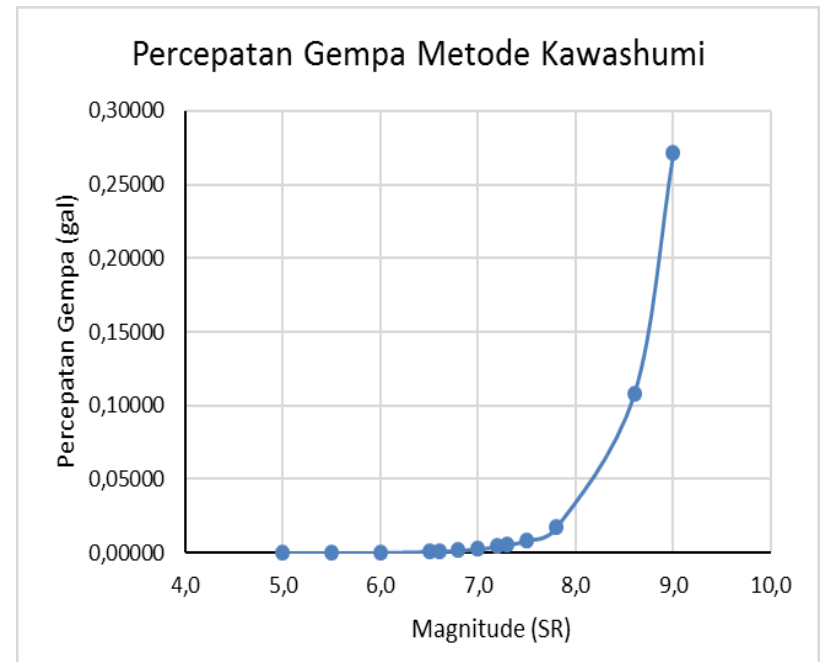

Gambar 7 Grafik Percepatan Gempa di Permukaan Tanah

Soelarno et al. (1983) yang dikutip oleh Marwan et al. [2] mempertimbangkan bahwa rumus empiris Donovan (1972) perlu dikoreksi sebesar 1 sampai dengan 2,5 untuk kondisi Indonesia. Perhitungan dalam penelitian ini, nilai percepatan gempa maksimum di permukaan tanah ini dikoreksi dengan faktor 2,5 untuk mendapatkan nilai yang paling aman.

Hasil yang diperoleh dari perhitungan percepatan gempa di permukaan tanah tersebut digunakan untuk melakukan perhitungan selanjutnya dalam menganalisis potensi likuifaksi pada lokasi pembangunan gedung Islamic Center At-Taqarrub Trienggadeng Pidie Jaya.

\subsubsection{Tegangan Efektif $\left(\sigma^{\prime}{ }_{\text {vo }}\right)$ dan Tegangan Total $\left(\sigma_{\mathrm{vo}}\right)$}

Dari data berat volume $(\gamma)$ dan kedalaman tanah yang ditinjau, dapat ditentukan tegangan vertikal, baik tegangan total maupun tegangan efektif. Kedalaman dan ketebalan lapisan yang ditinjau diketahui dari gambar susunan lapisan tanah (bor log). Untuk tegangan total dipakai $\gamma$ sesuai dengan titik data titik bor yang ditinjau, sedangkan untuk tegangan efektif dipakai $\gamma^{\prime}$ yang disesuaikan dengan data titik bor yang ditinjau. Nilai tegangan efektif tanah $\left(\sigma_{\mathrm{vo}}^{\prime}\right)$ dan tegangan total $\left(\sigma_{\mathrm{vo}}\right)$.

\subsubsection{Nilai Tahanan Standar Penetrasi yang Telah Dikoreksi (N')}

Nilai tahanan standar penetrasi (N-SPT) telah tersedia dari hasil pekerjaan pengeboran yang dilakukan di lapangan. Dengan mengetahui N-SPT dan besarnya tegangan efektif maka nilai standar penetrasi yang dikoreksi (N') dapat dihitung dengan persamaan 3 .

\subsubsection{Nilai Tahanan Standar Penetrasi (N-SPT)}

Nilai tahanan standar penetrasi (N-SPT) telah tersedia dari hasil pekerjaan pengeboran yang dilakukan di lapangan.

\subsubsection{Tegangan geser rata-rata akibat gempa $\left(\tau_{\mathrm{av}}\right)$}

Data percepatan gempa maksimum pada permukaan tanah, tegangan total, dan adanya faktor reduksi (rd), tegangan geser rata-rata akibat gempa $\left(\tau_{\mathrm{av}}\right)$ dapat dihitung dengan persamaan 4 .

\subsubsection{Penentuan kemungkinan likuifaksi menggunakan metode Castro (1975)}

Kriteria dalam menentukan terjadinya likuifaksi dengan menggunakan metode ini adalah memasukkan nilai tahanan penetrasi standar yang telah dikoreksi (N') pada kedalaman tanah yang ditinjau dengan nilai rasio tegangan gempa rata-rata $\left(\tau_{\mathrm{av}} / \sigma^{\prime}{ }_{\mathrm{vo}}\right)$, dimana $\tau_{\mathrm{av}}$ adalah tegangan geser gempa rata-rata dan $\sigma_{\text {vo }}^{\prime}$ adalah tegangan vertikal efektif, seperti yang diperlihatkan pada Gambar 2 dengan ketentuan sebagai berikut:

(a) Jika titik yang dihasilkan berada di sebelah kanan garis batas menunjukkan likuifaksi tidak terjadi;

(b) Jika titik yang dihasilkan berada di sebelah kiri garis batas menunjukkan likuifaksi terjadi; dan

Analisis menggunakan metode Castro (1975) dapat dilihat pada Tabel 3 dan Gambar 8 untuk bor $\log 1$ dan Tabel 4 dan Gambar 9 untuk bor $\log 2$.

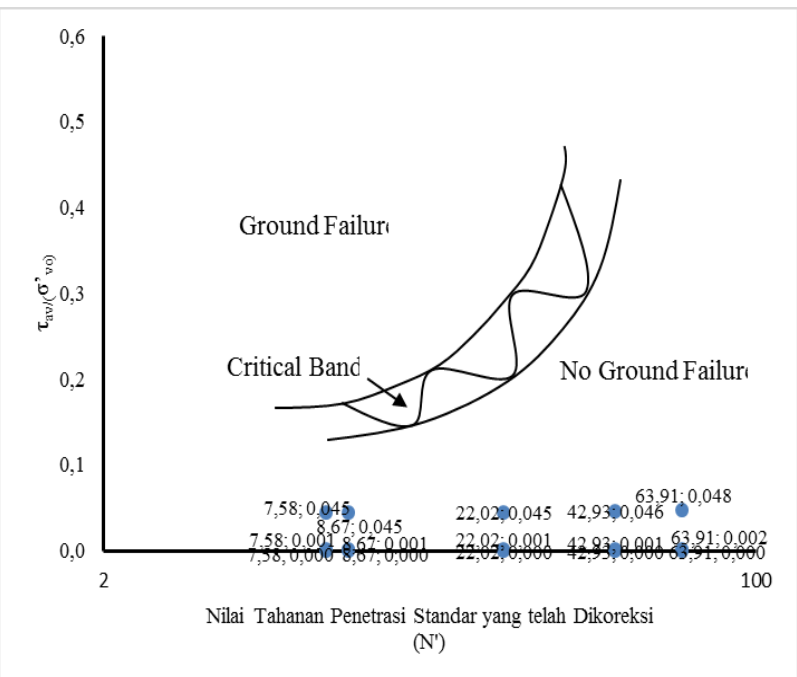

Gambar 8 Grafik hasil likuifaksi metode Castro (1975) bor $\log I$ 
Tabel 3. Analisis Potensi Likuifaksi Menggunakan Metode Castro (1975) dan Percepatan Gempa Maksimum Kawashumi Bor Log I.

\begin{tabular}{|c|c|c|c|c|c|c|c|c|c|c|c|}
\hline \multirow[t]{2}{*}{ No } & \multicolumn{2}{|c|}{ Kedalaman } & \multirow{2}{*}{$\begin{array}{c}\text { Magnitude } \\
\text { SR } \\
\end{array}$} & \multirow{2}{*}{$\begin{array}{l}\text { amax } \\
\text { gal }\end{array}$} & \multirow{2}{*}{$\begin{array}{l}\mathrm{Dr} \\
\%\end{array}$} & \multirow[t]{2}{*}{$\mathrm{rd}$} & \multirow{2}{*}{$\begin{array}{l}\sigma_{\mathrm{vo}} \\
\mathrm{kN} / \mathrm{m} 2\end{array}$} & \multirow{2}{*}{$\begin{array}{l}\sigma_{\mathrm{vo}}^{\prime} \\
\mathrm{kN} / \mathrm{m} 2\end{array}$} & \multirow{2}{*}{$\begin{array}{c}\tau_{\mathrm{av}} \\
\mathrm{kN} / \mathrm{m} 2\end{array}$} & \multirow[t]{2}{*}{$N^{\prime}$} & \multirow[t]{2}{*}{$\begin{array}{c}\text { Kemungkinan } \\
\text { Likuifaksi }\end{array}$} \\
\hline & $\mathrm{m}$ & $\mathrm{ft}$ & & & & & & & & & \\
\hline 1 & 2,45 & 8,4 & 5,0 & 0,00003 & 54,5 & 0,982 & 20,245 & 7,9950 & $0,000040,0,000005$ & 63,91 & Tidak Likuifaksi \\
\hline 2 & 4,45 & 14,60 & 5,0 & 0,00003 & 63,5 & 0,973 & 58,279 & 23,779 & $0,00010,0,000$ & 42,93 & Tidak Likuifaksi \\
\hline 3 & 6,45 & 21,16 & 5,0 & 0,00003 & 51,5 & 0,955 & 92,174 & 37,674 & $0,00020,000005$ & 22,02 & Tidak Likuifaksi \\
\hline 4 & 8,45 & 27,72 & 5,0 & 0,00003 & 31,7 & 0,932 & 123,779 & 49,379 & $0,00020,000005$ & 7,58 & Tidak Likuifaksi \\
\hline 5 & 10,45 & 34,28 & 5,0 & 0,00003 & 38,0 & 0,900 & 153,689 & 59,189 & $0,00030,0,000005$ & 8,67 & Tidak Likuifaksi \\
\hline 6 & 2,45 & 8,04 & 6,0 & 0,0003 & 54,5 & 0,982 & 20,245 & 7,995 & $0,0004 \quad 0,00005$ & 63,91 & Tidak Likuifaksi \\
\hline 7 & 4,45 & 14,60 & 6,0 & 0,0003 & 63,5 & 0,973 & 58,779 & 23,779 & $0,001 \quad 0,00005$ & 42,93 & Tidak Likuifaksi \\
\hline 8 & 6,45 & 21,16 & 6,0 & 0,0003 & 51,5 & 0,955 & 92,174 & 37,674 & $0,002 \quad 0,00005$ & 22,02 & Tidak Likuifaksi \\
\hline 9 & 8,45 & 27,72 & 6,0 & 0,0003 & 31,7 & 0,332 & 123,79 & 49,379 & $0,002 \quad 0,00005$ & 7,58 & Tidak Likuifaksi \\
\hline 10 & 10,45 & 34,28 & 6,0 & 0,0003 & 38,0 & 0,900 & 153,689 & 59,189 & $0,003 \quad 0,00005$ & 8,67 & Tidak Likuifaksi \\
\hline 11 & 2,45 & 8,4 & 6,5 & 0,0009 & 54,5 & 0,982 & 20,245 & 7,995 & $0,001 \quad 0,00015$ & 63,91 & Tidak Likuifaksi \\
\hline 12 & 4,45 & 14,60 & 6,5 & 0,0009 & 63,5 & 0,973 & 58,279 & 23,779 & $0,003 \quad 0,00015$ & 42,93 & Tidak Likuifaksi \\
\hline 13 & 6,45 & 21,16 & 6,5 & 0,0009 & 51,5 & 0,955 & 92,174 & 37,674 & $0,005 \quad 0,00014$ & 22,02 & Tidak Likuifaksi \\
\hline 14 & 8,45 & 27,72 & 6,5 & 0,0009 & 31,7 & 0,332 & 123,779 & 49,379 & $0,007 \quad 0,00014$ & 7,58 & Tidak Likuifaksi \\
\hline 15 & 10,45 & 34,28 & 6,5 & 0,0009 & 38,0 & 0,900 & 153,689 & 59,189 & $0,008 \quad 0,00014$ & 8,67 & Tidak Likuifaksi \\
\hline 16 & 2,45 & 8,4 & 7,5 & 0,0086 & 54,5 & 0,982 & 20,245 & 7,995 & $0,012 \quad 0,00152$ & 63,91 & Tidak Likuifaksi \\
\hline 17 & 4,45 & 14,60 & 7,5 & 0,0086 & 63,5 & 0,973 & 58,279 & 23,79 & $0,035 \quad 0,00146$ & 42,93 & Tidak Likuifaksi \\
\hline 18 & 6,45 & 21,16 & 7,5 & 0,0086 & 51,5 & 0,955 & 92,174 & 37,674 & $0,054 \quad 0,00143$ & 22,02 & Tidak Likuifaksi \\
\hline 19 & 8,45 & 27,72 & 7,5 & 0,0086 & 31,7 & 0,932 & 123,779 & 49,379 & $0,071 \quad 0,00143$ & 7,58 & Tidak Likuifaksi \\
\hline 20 & 10,45 & 34,28 & 7,5 & 0,0086 & 38,0 & 0,900 & 153,689 & 59,189 & $0,085 \quad 0,00143$ & 8,67 & Tidak Likuifaksi \\
\hline 21 & 2,45 & 8,04 & 9,0 & 0,2715 & 54,5 & 0,982 & 20,45 & 7,995 & $\begin{array}{ll}0,385 & 0,04818\end{array}$ & 63,91 & Tidak Likuifaksi \\
\hline 22 & 4,45 & 14,60 & 9,0 & 0,2715 & 63,5 & 0,973 & 58,279 & 23,779 & $1,099 \quad 0,04620$ & 42,93 & Tidak Likuifaksi \\
\hline 23 & 6,45 & 21,16 & 9,0 & 0,2715 & 51,5 & 0,955 & 22,174 & 37,674 & $1,705 \quad 0,04527$ & 22,02 & Tidak Likuifaksi \\
\hline 24 & 8,45 & 27,72 & 9,0 & 0,2715 & 31,7 & 0,332 & 123,779 & 49,379 & $2,237 \quad 0,04530$ & 7,58 & Tidak Likuifaksi \\
\hline 25 & 10,45 & 34,28 & 9,0 & 0,2715 & 38,0 & 0,900 & 153,689 & 59,189 & $2,680 \quad 0,04528$ & 8,67 & Tidak Likuifaksi \\
\hline
\end{tabular}

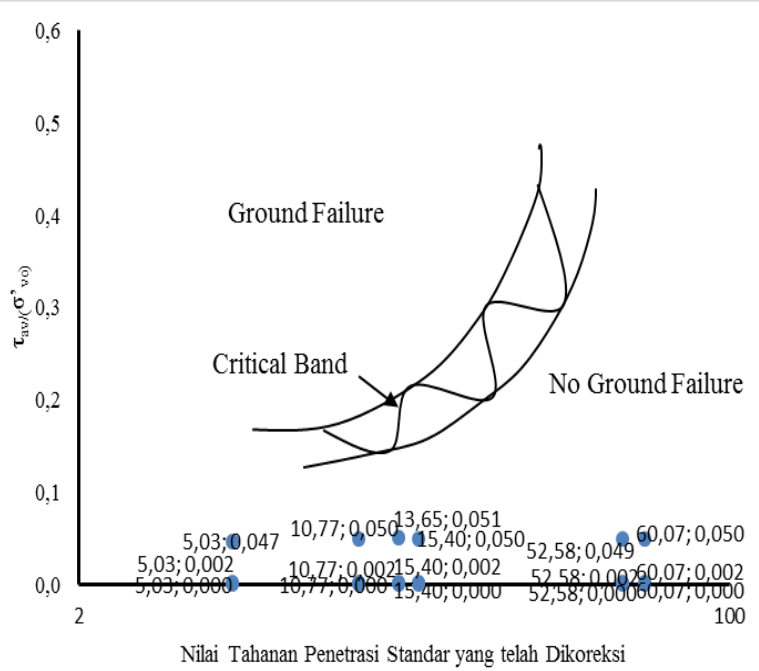

(N')

Gambar 9 Grafik hasil likuifaksi metode Castro (1975) bor log II
Tabel 4. Analisis Potensi Likuifaksi Menggunakan Metode Castro (1975) dan Percepatan Gempa Maksimum Kawashumi Bor Log II.

\begin{tabular}{|c|c|c|c|c|c|c|c|c|c|c|c|}
\hline \multirow{2}{*}{ No } & \multicolumn{2}{|c|}{ Kedalaman } & \multirow{2}{*}{$\begin{array}{c}\text { Magnitude } \\
\text { SR }\end{array}$} & \multirow{2}{*}{$\begin{array}{l}\text { amax } \\
\text { gal }\end{array}$} & \multirow{2}{*}{ rd } & \multirow{2}{*}{$\sigma_{\mathrm{vo}}$} & \multirow{2}{*}{$\sigma_{\text {vo }}^{\prime}$} & \multirow[b]{2}{*}{$\mathrm{kN} / \mathrm{m} 2$} & \multirow{2}{*}{$\frac{\tau_{a v}}{\sigma_{v 0}^{\prime}}$} & & \multirow{2}{*}{$\begin{array}{c}\text { Kemungkinan } \\
\text { Likuifaksi }\end{array}$} \\
\hline & $\mathrm{m}$ & $\mathrm{ft}$ & & & & & & & & & \\
\hline 1 & 2,45 & 8,04 & 5,0 & 0,0000 & 0,982 & 19,729 & 7,479 & 0,00004 & 0,00001 & 60,07 & Tidak Likuifaksi \\
\hline 2 & 4,45 & 14,60 & 5,0 & 0,0000 & 0,973 & 55,879 & 21,379 & 0,0001 & 0,000005 & 52,58 & Tidak Likuifaksi \\
\hline 3 & 6,45 & 21,16 & 5,0 & 0,0000 & 0,955 & 86,721 & 32,221 & 0,0002 & 0,000005 & 15,40 & Tidak Likuifaksi \\
\hline 4 & 8,45 & 27,72 & 5,0 & 0,0000 & 0,932 & 115,774 & 41,274 & 0,0002 & 0,00001 & 13,65 & Tidak Likuifaksi \\
\hline 5 & 10,45 & 34,28 & 5,0 & 0,0000 & 0,900 & 144,826 & 50,326 & 0,0003 & 0,00001 & 10,77 & Tidak Likuifaksi \\
\hline 6 & 12,45 & 40,84 & 5,0 & 0,0000 & 0,836 & 174,047 & 59,547 & 0,0003 & 0,00000 & 5,03 & Tidak Likuifaksi \\
\hline 7 & 2,45 & 8,04 & 6,0 & 0,0003 & 0,982 & 19,729 & 7,479 & 0,0004 & 0,00005 & 60,07 & Tidak Likuifaksi \\
\hline 8 & 4,45 & 14,00 & 6,0 & 0,0003 & 0,973 & 55,879 & 21,379 & 0,001 & 0,00005 & 52,58 & Tidak Likuifaksi \\
\hline 9 & 6,45 & 21,16 & 6,0 & 0,0003 & 0,955 & 86,721 & 32,221 & 0,002 & 0,00005 & 15,40 & Tidak Likuifaksi \\
\hline 10 & 8,45 & 27,72 & 6,0 & 0,0003 & 0,932 & 115,774 & 41,274 & 0,002 & 0,00005 & 13,65 & Tidak Likuifaksi \\
\hline 11 & 10,45 & 34,28 & 6,0 & 0,0003 & 0,900 & 144,226 & 50,326 & 0,003 & 0,00005 & 10,77 & Tidak Likuifaksi \\
\hline 12 & 12,45 & 40,84 & 6,0 & 0,0003 & 0,836 & 174,047 & 59,547 & 0,003 & 0,00005 & 5,03 & Tidak Likuifaksi \\
\hline 13 & 2,45 & 8,04 & 6,5 & 0,0009 & 0,982 & 19,729 & 7,479 & 0,001 & 0,00016 & 60,07 & Tidak Likuifaksi \\
\hline 14 & 4,45 & 14,00 & 6,5 & 0,0009 & 0,973 & 55,879 & 21,379 & 0,003 & 0,00016 & 52,58 & Tidak Likuifaksi \\
\hline 15 & 6,45 & 21,16 & 6,5 & 0,0009 & 0,955 & 86,721 & 32,221 & 0,005 & 0,00016 & 15,40 & Tidak Likuifaksi \\
\hline 16 & 8,45 & 27,72 & 6,5 & 0,0009 & 0,932 & 115,774 & 41,274 & 0,007 & 0,00016 & 13,65 & Tidak Likuifaksi \\
\hline 17 & 10,45 & 34,28 & 6,5 & 0,0009 & 0,900 & 14,826 & 50,326 & 0,008 & 0,00016 & 10,77 & Tidak Likuifaksi \\
\hline 18 & 12,45 & 40,84 & 6,5 & 0,0009 & 0,836 & 174,047 & 59,547 & 0,009 & 0,00015 & 5,03 & Tidak Likuifiaksi \\
\hline 19 & 2,45 & 8,04 & 7,5 & 0,0086 & 0,982 & 19,729 & 7,479 & 0,012 & 0,00159 & 60,07 & Tidak Likuifaksi \\
\hline 20 & 4,45 & 14,60 & 7,5 & 0,0086 & 0,973 & 55,879 & 21,379 & 0,033 & 0,00156 & 52,58 & Tidak Likuifaksi \\
\hline 21 & 6,45 & 21,16 & 7,5 & 0,0086 & 0,955 & 86,721 & 32,221 & 0,051 & 0,00157 & 15,40 & Tidak Likuifaksi \\
\hline 22 & 8,45 & 27,72 & 7,5 & 0,0086 & 0,932 & 115,774 & 41,274 & 0,066 & 0,00160 & 13,65 & Tidak Likuifaksi \\
\hline 23 & 10,45 & 34,28 & 7,5 & 0,0086 & 0,900 & 144,826 & 50,326 & 0,080 & 0,00159 & 10,77 & Tidak Likuifaksi \\
\hline 24 & 12,45 & 40,84 & 7,5 & 0,0086 & 0,836 & 174,047 & 59,547 & 0,089 & 0,00150 & 5,03 & Tidak Likuifaksi \\
\hline 25 & 2,45 & 8,04 & 9,0 & 0,2715 & 0,982 & 19,729 & 7,479 & 0,375 & 0,05019 & 60,07 & Tidak Likuifaksi \\
\hline 26 & 4,45 & 14,60 & 9,0 & 0,2715 & 0,973 & 55,879 & 21,379 & 1,053 & 0,04927 & 52,58 & Tidak Likuifaksi \\
\hline 27 & 6,45 & 21,16 & 9,0 & 0,2715 & 0,955 & 86,721 & 32,221 & 1,005 & 0,44980 & 15,40 & Tidak Likuifaksi \\
\hline 28 & 8,45 & 27,72 & 9,0 & 0,2715 & 0,932 & 115,774 & 41,274 & 2,091 & 0,05065 & 13,65 & Tidak Likuifaksi \\
\hline 29 & 10,45 & 34,28 & 9,0 & 0,2715 & 0,900 & 144,226 & 50,326 & 2,525 & 0,05018 & 10,77 & Tidak Likuifaksi \\
\hline 30 & 12,45 & 40,84 & 9,0 & 0,2715 & 0,836 & 174,047 & 59,547 & 2,819 & 0,04734 & 5,03 & Tidak Likuifaksi \\
\hline
\end{tabular}

\subsection{Pembahasan}

Likuifaksi yang ditinjau pada penelitian ini ialah likuifaksi yang terjadi akibat pembebanan cyclic, yaitu likuifaksi yang biasanya terjadi pada tanah pasir jenuh air yang mengalami getaran gempa sehingga pasir kehilangan kekuatan daya dukungnya. Oleh karena itu, lapisan yang ditinjau hanya lapisan tanah pasir jenuh air saja, dimana lapisan pasir tersebut harus berada dibawah muka air tanah.

Metode yang digunakan untuk menganalisis potensi likufaksi adalah metode Castro (1975). Hasil potensi likuifaksi dengan berdasarkan pengambilan magnitude gempa dari 5.0, 6.0, 6.5, 7.5, dan 9.0 SR akan memberikan hasil yang bervariasi.

Pada metode yang diusulkan Castro (1975) sangat tergantung dari nilai cycle ratio, yaitu hubungan perbandingan antara nilai tegangan geser gempa rata-rata 
$\left(\boldsymbol{\tau}_{\boldsymbol{e q}}\right)$ dengan nilai tegangan vertikal efektif $\left(\boldsymbol{\sigma}^{\prime}{ }_{\mathbf{v o}}\right)$ dan nilai kepadatan penetrasi standar yang telah dikoreksi (N'). Bila nilai $N^{\prime}$ yang melebihi 50, tidak terjadi likuifaksi disebabkan garis likuifaksi hanya terbatas pada nilai N' sampai 50.

Nilai percepatan gempa maksimum di permukaan tanah $\left(\mathrm{a}_{\max }\right)$ pada penelitian ini menggunakan persamaan Kawashumi. Nilai percepatan gempa maksimum di permukaan tanah ini sangat bergantung pada magnitude dan jarak pusat gempa dengan lokasi yang ditinjau. Semakin dekat jarak pusat gempa dengan lokasi yang ditinjau maka potensi likuifaksi yang terjadi semakin tinggi.

\section{Kesimpulan dan Saran}

\subsection{Kesimpulan}

Berdasarkan hasil analisis dan pembahasan yang telah diuraikan sebelumnya, hasil analisis potensi likuifaksi pada Gedung Islamic Center At-Taqarrub Trienggadeng Pidie Jaya dapat diambil kesimpulan sebagai berikut:

1. Menurut metode Castro (1975) pada percepatan dengan metode percepatan gempa Kawashumi pada titik bor log 1 tidak mengalami likuifaksi pada setiap lapisan dan setiap magnitude gempa rencana.

2. Pada metode Castro (1975) pada percepatan dengan metode percepatan gempa Kawashumi Pada titik bor $\log 2$ juga tidak mengalami likuifaksi pada setiap lapisan dan setiap magnitude gempa rencana.

\subsection{Saran}

Setelah melakukan perhitungan analisis potensi likuifaksi, disarankan beberapa hal berikut ini:

1. Dalam mempertimbangkan likuifaksi disarankan menggunakan metode-metode lainnya antara lain Kishida (1969, Whitman (1971), Seed \& Idris (1971), Seed et al. (1976) dan Valera \& Donovan (1977) yang sesuai dengan parameter yang tersedia pada objek yang akan diteliti .

2. Pada saat membuat sebuah konstruksi besar di daerah-daerah yang diketahui memiliki potensi likuifaksi yang tinggi, sebaiknya dibuat stone column atau perbaikan tanah lainnya seperti grouting dan pemadatan untuk mengurangi risiko terjadinya likuifaksi.

\section{Ucapan Terima Kasih}

Terimakasih kepada Bapak Prof. Dr. Ir. Munirwansyah, M.Sc, yang telah ikut membimbing dan memberikan dukungan dan masukan-masukan terkait data dalam pembantu penelitian Skim Penelitian P.P tahun 2019 no.520/UNII/SPIL/PNBP/2019 tanggal 08 Februari 2019.

\section{Daftar Pustaka}

1. Kementerian Pekerjaan Umum dan Perumahan Rakyat, Kajian Gempa Pidie Jaya Provinsi Aceh Indonesia, Bandung, 2016.

2. Marwan, Isya, M., dan Bahagia, Analisis Potensi Likuifaksi pada Jembatan Laguna Meuraxa Kota Banda Aceh, Jurnal Teknik Sipil Universitas Syiah Kuala, Banda aceh, 2011.

3. Bowles, J.E., Sifat - Sifat Fisis dan Geoteknik Tanah, Terjemahan Loeh Hainim J. K, Penerbit Erlangga, Jakarta, 1984.

4. Susantri, T, Analisis Potensi Likuifaksi Lapisan Pasir pada Lokasi Pelabuhan Malahayati Krueng Raya Aceh Besar (Menggunakan Analisis dari Seed et al., Kishida, dan Castro), Universitas Syiah Kuala, Banda Aceh, 2011.

5. CV. Rekayasa Andalan, Laporan Akhir Pekerjaan Penyelidikan Tanah Pembangunan Islamic Center At-Taqarrub, Trieng Gadeng Pidie Jaya, Banda Aceh, 2017.

6. Badan Meteorologi, Klimatologi dan Geofisika, Laporan Data Gempa Bumi Teranalisa di Wilayah Aceh Tahun 2015-2019, Banda Aceh, 2019. 